\title{
Effect of Diethylstilboestrol on Adipose-Tissue Lipids
}

\author{
By J. D. SINK, C. K. HUSTON* AND J. W. SHIGLEY \\ Departments of Animal Industry and Nutrition and Biochemistry, \\ Pennsylvania State University, University Park, Pa., U.S.A.
}

(Received 22 March 1965)

\begin{abstract}
1. The effect of diethylstilboestrol on the fatty acid composition of adipose-tissue lipids of the ox (Bos taurus) was studied. 2. The capsula adiposa (perirenal) was shown to contain more total saturated fatty acids, whereas more total unsaturated fatty acids were found in the panniculus adiposus (subcutaneous). 3. Significantly more stearic acid and linolenic acid were obtained from the capsula adiposa, whereas the panniculus adiposus contained more myristoleic acid, palmitoleic acid and oleic acid. 4. Implanting diethylstilboestrol significantly increased the deposition of the saturated fatty acids, particularly stearic acid. 5. A decrease in the deposition of total unsaturated fatty acids, myristoleic acid, palmitoleic acid and linoleic acid can also be attributed to the diethylstilboestrol treatment.
\end{abstract}

Diethylstilboestrol ( $\alpha \alpha^{\prime}$-diethylstilbenediol) was first synthesized by Dodds, Goldberg, Lawson \& Robinson (1938, 1939), and during the past 25 years it has found application in human medicine (Goth, 1964) as well as in animal nutrition (Riggs, 1958).

Pioneering the use of diethylstilboestrol in animal nutrition, Burroughs, Culbertson, Kastelic, Cheng \& Hale (1954) and Burroughs, Culbertson, Cheng, Hale \& Homeyer (1955) reported growth stimulation from feeding with trace amounts of this synthetic material. More detailed studies, on its effect on the composition of the animal body (Stouffer, Bull, Breidenstein, Neumann \& Albert, 1956; Ogilvie, Faltin, Hauser, Bray \& Hoekstra, 1960; Wilson, Dinkel, Roy \& Minyard, 1963) as well as on the various endocrine organs (Burgess \& Lamming, 1960), followed these initial efforts. Edwards, Tove, Blumer \& Barrick (1961) reported that implants of diethylstilboestrol affected the deposition of certain fatty acids.

However, no detailed information exists about the effect of diethylstilboestrol on the spectrum of fatty acids that are found in the adipose tissues of the animal body. Consequently, it was the purpose of the present research to investigate, qualitatively and quantitatively, the effect of this synthetic hormone material on the fatty acid composition of certain adipose tissues.

\section{MATERIALS AND METHODS}

Sampling and extraction. Twelve castrated male experimental oxen (Bos taurus) were used in these studies. Six of

* Present address: U.S. Army Biological Laboratories, Ft. Detrick, Frederick, Md., U.S.A. these animals had received $24 \mathrm{mg}$. implants of diethylstilboestrol (Eli Lilly and Co., Indianapolis, Ind., U.S.A.) and the other six served as control animals. Samples of the capsula adiposa (perirenal) and the panniculus adiposus (subcutaneous) adipose tissues were taken from the carcasses of the animals at $24 \mathrm{hr}$. post mortem.

Then $80 \mathrm{~g}$. portions of the adipose tissue samples were cut into small pieces and extracted three times in a Waring Blendor with a total of $500 \mathrm{ml}$. of diethyl ether. The ether solution was filtered and dried over anhydrous $\mathrm{Na}_{2} \mathrm{SO}_{4}$ and the excess of solvent was removed from the extract with a Rinco Evaporator.

Fatty acid methylation. A $50 \mathrm{mg}$. portion of the lipid was treated in a $15 \mathrm{ml}$. centrifuge tube with $5 \mathrm{ml}$. of $0.5 \%(\mathrm{w} / \mathrm{v})$ $\mathrm{H}_{2} \mathrm{SO}_{4}$ in methanol in a $70^{\circ}$ water bath for $2 \mathrm{hr}$. After the tubes had been cooled, $2 \mathrm{ml}$. of light petroleum (b.p. 30-80 was added. The light petroleum was washed with water, transferred to a sample vial and the excess of solvent evaporated by a stream of $\mathrm{N}_{2}$.

Gas-liquid-chromatographic analysis. Samples $(2 \mu 1$.$) of$ the methylated fatty acids were chromatographed on a Barber-Colman model 10 gas chromatograph equipped with a $2.75 \mathrm{~m}$. glass column. The column was packed with Chromosorb-W (80-100 mesh) containing 17\% (by weight) of ethylene glycol succinate polyester as the liquid phase (Applied Science Laboratories, State College, Pa., U.S.A.). The chromatography was accomplished under the following conditions: column temperature, $190^{\circ}$; detector temperature, $235^{\circ}$; flash-heater temperature, $260^{\circ}$; argon inlet pressure, $40 \mathrm{lb}$./in. ${ }^{2}$ (gauge); high voltage, $750 \mathrm{v}$. Samples of known methyl esters (Applied Science Laboratories, State College, Pa.) were chromatographed to identify the individual components. The percentages (by weight) of the various fatty acid methyl esters were determined from the peak areas, previously computed by triangulation.

An analysis of variance ( $F$-test) was used to test for significant differences among the means of the various groups. Differences between the means of the different groups were tested by the method of Tukey as outlined by Snedecor (1956). 


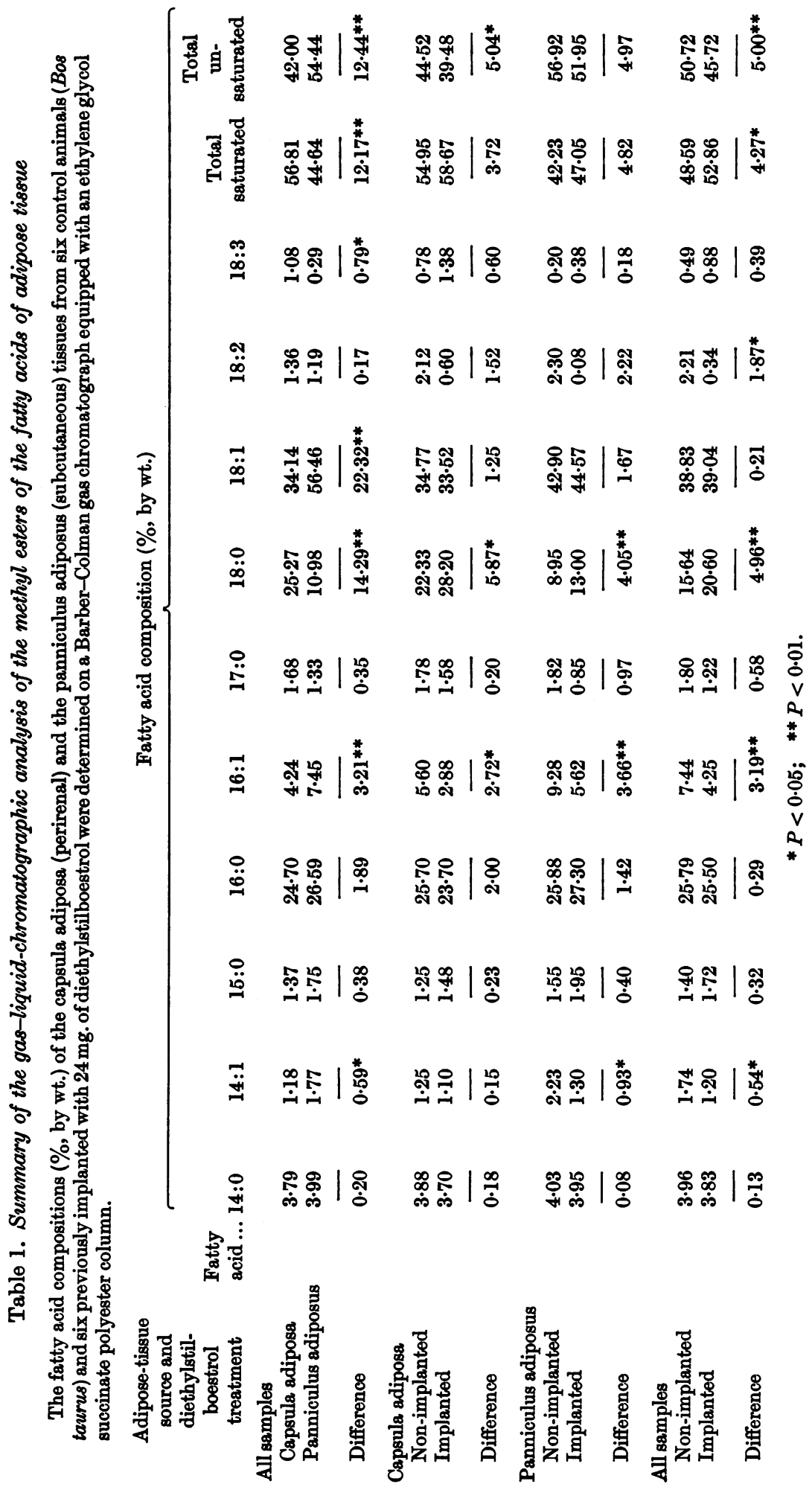




\section{RESULTS}

Adipose-tissue differences. The statistical analysis of the gas-liquid-chromatographic data (Table 1) showed adipose-tissue source differences in fatty acid composition. The capsula adiposa contained more total saturated fatty acids $(P<0.01)$ as well as more stearic acid $(18: 0)(P<0.01)$ and the polyunsaturated $\mathrm{C}_{18}$ fatty acid linolenic acid (18:3) $(P<0.05)$, whereas more total unsaturated fatty acids $(P<0.01)$, myristoleic acid $(14: 1)(P<0.05)$, palmitoleic acid $(16: 1)(P<0.01)$ and oleic acid (18:1) $(P<0.01)$ were found in the panniculus adiposus source.

Stilboestrol-treatment differences. The implantation of diethylstilboestrol was found (Table 1) to have a highly significant $(P<0.01)$ depressing effect on the amount of total unsaturated fatty acids in the adipose tissues as well as on the amount of palmitoleic acid. A significant $(P<0.05)$ decrease in the amounts of myristoleic acid and linoleic acid $(18: 2)$ in the diethylstilboestrol-treated animals was also noted. The non-implanted or control animals contained more palmitoleic acid and total unsaturated fatty acids in the capsula adiposa as well as more myristoleic acid and palmitoleic acid in the panniculus adiposus than those implanted with diethylstilboestrol. A highly significant $(P<0.01)$ difference in the stearic acid content and a significant $(P<0.05)$ difference in the total amount of saturated fatty acids in favour of the implanted animals was observed. The implanted animals contained more stearic acid in both adipose tissues than did the non-implanted animals. The interaction of source and treatment was not significant.

\section{DISCUSSION}

Since the amounts of components other than glycerides (i.e. phospholipids, sterols etc.) reported to be found in bovine adipose tissues is very small (Lange, 1950; Bailey, 1951), it was decided for the purposes of these experiments to assume that the ether extracts of the adipose tissues were composed of glycerides only.

Adipose-tissue differences. From previous adipose-tissue experiments in our Laboratory (Huston, Sink, Miller \& Shigley, 1965), the differences observed in the fatty acid compositions of the capsula adiposa (perirenal) and the panniculus adiposus (subcutaneous) tissues were expected. Studies investigating this predominance of the saturated fatty acids in the capsula adiposa and the unsaturated fatty acids in the panniculus adiposus were initiated after the early work of Banks \& Hilditch (1931). The work of Lovern (1936) showed that higher body temperatures resulted in an increase in the amount of saturated fatty acids and an increase in the length of the carbon chain. Hilditch (1956) attributes the phenomenon to the different temperatures in these two tissues. The more saturated fatty acids, with their correspondingly higher melting points, are therefore found in those body tissues that have a higher body temperature. The reverse is true for the unsaturated fatty acids. The principal fatty acids involved in this feature of adipose-tissue physiology are oleic acid and stearic acid. In the castrated controls, the oleic acid/stearic acid ratio in the capsula adiposa was 1.85 whereas in the panniculus adiposus it was 4.80. In the implanted castrated animals, it was 1.19 and 3.44 respectively.

Stilboestrol-treatment differences. The sex hormones control the development of secondary sex characteristics and, consequently, the amount and distribution of the adipose tissues (Deuel, 1955). Most of the female sex hormones or oestrogens, normally present in the intact male, are produced from testosterone precursors (Ahmad \& Morse, 1965; Beard, Jellinick \& O'Donnell, 1955) under the influence of and/or secreted by the testes or the adrenals or both. Givner, Bauld, Hale, Vagi \& Nilsen (1960) have demonstrated that the administration of chorionic gonadotrophin or adrenocorticotrophic hormone resulted in an elevated oestrogen concentration, whereas Morse, Clark, MacLeod, Ernst \& Gosse (1962) observed that castration lowered the concentration. Dahl (1962), in studying the effect of castration on the fatty acid composition of certain bovine adipose tissues, observed that the tissues from the uncastrated or intact male contained significantly more saturated fatty acids, especially stearic acid. In the adipose tissues from the castrated male, he found significantly more unsaturated fatty acids. In addition, more myristoleic acid, palmitoleic acid and linoleic acid were also present in these tissues. Our results from implanting $24 \mathrm{mg}$. of diethylstilboestrol produced a very similar effect. Greater deposition of the saturated fatty acids and stearic acid was found in the adipose tissues of the implanted castrated males. The control or non-implanted male castrated animals contained more total unsaturated fatty acids, myristoleic acid, palmitoleic acid and linoleic acid in their adipose tissues. These results suggest that this synthetic oestrogen is acting somewhat like the natural sex hormones in controlling the deposition of fatty acids in adipose tissue. Though considerable uncertainty still exists about both the mechanism by which these effects are mediated and the identity of the hormones responsible for the observed metabolic alterations, recent evidence (Hess, 1964) indicates that diethylstilboestrol may influence lipid metabolism through its effect on the secretory activity of the anterior pituitary or 
through decreasing the peripheral utilization of the thyroid hormone or both.

This is Journal Series Paper no. 2909 of the Pennsylvania Agricultural Experiment Station.

\section{REFERENCES}

Ahmad, N. \& Morse, W. I. (1965). Canad. J. Biochem. 43, 25.

Bailey, A. E. (1951). Industrial Oil and Fat Products, p. 142. New York: Interscience Publishers Inc.

Banks, A. \& Hilditch, T. P. (1931). Biochem. J. 25, 1168.

Beard, R. D. H., Jellinick, P. H. \& O'Donnell, V. J. (1955). Endocrinology, 57, 200.

Burgess, T. D. \& Lamming, G. E. (1960). Anim. Prod. 2, 93.

Burroughs, W., Culbertson, C. C., Cheng, E., Hale, W. H. \& Homeyer, P. (1955). J. Anim. Sci. 14, 1015.

Burroughs, W., Culbertson, C. C., Kastelic, J., Cheng, E. \& Hale, W. H. (1954). Science, 120, 66.

Dahl, O. (1962). J. Sci. Fd Agric. 13, 520.

Deuel, H. J., jun. (1955). The Lipids, vol. 2, p. 583. New York: Interscience Publishers Inc.

Dodds, E. C., Goldberg, L., Lawson, W. \& Robinson, R. (1938). Nature, Lond., 141, 247.
Dodds, E. C., Goldberg, L., Lawson, W. \& Robinson, R. (1939). Proc. Roy. Soc. B, 27, 140.

Edwards, R. L., Tove, S. B., Blumer, T. N. \& Barrick, E. R. (1961). J. Anim. Sci. 20, 712.

Givner, M. L., Bauld, W. S., Hale, T. R., Vagi, K. \& Nilsen, M. (1960). J. clin. Endocrin. Metab. 20,665.

Goth, A. (1964). Medical Pharmacology, p. 426. St Louis: The C. V. Mosby Co.

Hess, R. (1964). Advanc. Lipid Res. 2, 295.

Hilditch, T. P. (1956). The Chemical Constitution of Natural Fats, p. 99. London: Chapman and Hall Ltd. Huston, C. K., Sink, J. D., Miller, R. C. \& Shigley, J. W. (1965). J. Amer. Oil Chem. Soc. 42, 141.

Lange, W. (1950). J. Amer. Oil Chem. Soc. 27, 414.

Lovern, J. A. (1936). Biochem. J. 20, 2023.

Morse, W. I., Clark, A. F., MacLeod, S. C., Ernst, W. A. \& Gosse, C. L. (1962). J. clin. Endocrin. Metab. 22, 678.

Ogilvie, M. L., Faltin, E. C., Hauser, E. R., Bray, R. W. \& Hoekstra, W. G. (1960). J. Anim. Sci. 19, 991.

Riggs, J. K. (1958). J. Anim. Sci. 17, 981.

Snedecor, G. W. (1956). Statistical Methods, p. 237. Ames: Iowa State College Press.

Stouffer, J. R., Bull, S., Breidenstein, B. C., Neumann, A. L. \& Albert, W. W. (1956). J. Anim. Sci. 15, 1267.

Wilson, L. L., Dinkel, C. A., Roy, D. E. \& Minyard, J. A. (1963). J. Anim. Sci. 22, 699. 